\title{
S6 Kinase 2 Deficiency Improves Glucose Disposal in Mice Fed a High Fat Diet
}

Kristin M Taylor ${ }^{1 *}$, Jeffrey Bajko ${ }^{1}$, Mario S Cabrera ${ }^{1}$, Cliff Kremer ${ }^{2}$, Birgit Meyer-Puttlitz ${ }^{2}$, Anke M Schulte ${ }^{2}$, Seng H Cheng ${ }^{1}$, Ronald K Scheule ${ }^{1}$ and Rodney J Moreland ${ }^{1 *}$

${ }^{1}$ Genzyme, a Sanofi Company, Framingham, USA

${ }^{2}$ Sanofi Corporation, Frankfurt, Germany

\begin{abstract}
The mammalian target of rapamycin complex 1 (mTORC1) regulates insulin-mediated glucose metabolism, cell proliferation, the oxidative branch of the pentose phosphate pathway, de novo lipogenesis, and autophagy. Ribosomal S6 kinase 1 (S6K1) and 2 (S6K2) are downstream effectors of mTORC1. To characterize the role of S6K2 in insulin-mediated metabolism, the response of S6K2 deficient mice (S6K2-/-) to a glucose challenge was compared to that of wild-type (C57BL/6) and diabetes resistant strains (BALB/C and A/J) after 35 weeks on a high fat diet (HFD). Although S6K2-/- mice fed a HFD gained as much weight as the wild-type C57BL/6 control mice, unlike the wild-type mice they remained glucose tolerant, insulin sensitive, and had lower basal blood glucose levels. Moreover, unlike S6K1 deficient mice, S6K2-/- mice have increased basal plasma insulin levels and increased $\beta$-cell mass compared to C57BL/6, BALB/c, and A/J mice. Administration of insulin to S6K2-/- and C57BL/6 mice fed a Standard Diet (SD) resulted in phosphorylation of Ser307 on skeletal muscle Insulin Receptor Substrate 1 (IRS-1); however, when both strains were fed a HFD, phosphorylation of IRS-1 Ser307 was maintained in S6K2-/- mice but inhibited in C57BL/6 mice. Taken together, these results suggest that S6K2 inhibition may represent a strategy for treating type 2 diabetes.
\end{abstract}

Keywords: Glucose tolerance test; Insulin tolerance test; $\beta$-cell mass; S6K2; Diabetes

\section{Introduction}

The mammalian Target of Rapamycin (mTOR) senses cellular energy and can either promote cell growth and proliferation or induce catabolism and autophagy. mTOR is a conserved serine/threonine kinase that exists in several distinct multi-protein complexes such as mTORC1 (containing raptor) and mTORC2 (containing rictor) [13]. mTORC1 regulates autophagy and metabolic pathways, including glycolysis, de novo lipid biosynthesis, and the oxidative arm of the pentose phosphate pathway [4]. An additional mTORC1-regulated pathway was revealed when we treated Pompe mice with rapamycin and observed the abatement of lysosomal glycogen accumulation in skeletal muscle [5]. Hence, a better understanding of how mTORC1 interfaces with these diverse metabolic pathways in different tissues may lead to new therapies to treat Pompe disease as well as other metabolic disorders such as type 2 diabetes.

The most characterized substrate of mTORC1 is ribosomal S6 kinase 1 (S6K1). S6K1 deficient mice on a High Fat Diet (HFD) exhibit improved insulin sensitivity and are protected against obesity when compared to HFD-fed wild-type controls [6]. Hence, inhibiting S6K1 is currently being considered as a potential strategy to treat type 2 diabetes [7]. However, S6K1 inhibition has several potential untoward effects. For example, S6K1 deficient mice on a Standard Diet (SD) are glucose intolerant, hypoinsulinemic, and have reduced $\beta$-cell mass [8].

Less is known about ribosomal S6 kinase 2 (S6K2), another mTORC1 substrate. S6K2 shares $84 \%$ amino acid identity with S6K1 in the kinase domain and less than $60 \%$ homology in the $\mathrm{N}$ - and C-terminal regions [9]. A recent report demonstrated that unlike S6K1-/- mice, mice deficient in both S6K1 and S6K2 had normal glucose tolerance on SD and improved glucose tolerance on HFD when compared to wildtype mice [10]. Based on these results, we asked whether a deficiency in S6K2 alone might improve glucose tolerance on a HFD and thereby avoid the negative effects associated with S6K1 deficiency.
The aim of this study was to assess glucose tolerance and insulin sensitivity in S6K2-/- mice and compare the responses to diabetes susceptible wild-type (C57BL/6) mice and diabetes resistant strains (BALB/c, A/J) when placed on a SD or HFD [11]. We demonstrated that $\mathrm{S} 6 \mathrm{~K} 2-/-$ mice on SD have higher basal plasma insulin levels than C57BL/6, BALB/c and A/J mice. On a HFD, S6K2-/- mice exhibited improved glucose tolerance and insulin sensitivity compared to wildtype C57BL/6 mice. The results of these studies support the notion that inhibiting S6K2 may represent a viable approach for treating type 2 diabetes.

\section{Materials and Methods}

\section{Materials}

ELISA kits (Total IRS-1, IRS-1 phospho Ser307, Total IR $\beta$, IR $\beta$ phospho panTyr) were obtained from Cell Signaling (Beverly, MA). Adiponectin, insulin, and leptin ELISA kits were from EMD Millipore (Billerica, MA). BCA kit for protein determinations was from Pierce (Rockford, Ill). Humulin $\mathrm{N}$ was obtained from Eli Lilly (Indianapolis, IN). Glucose was obtained from Sigma (St. Louis, MO).

\section{Animal studies}

Animal experiments were conducted in accordance with Genzyme’s

*Corresponding author: Kristin M. Taylor, Genzyme Corporation, 49 New YorkAvenue Framingham, MA, USA, Tel: (508) 270-2425; E-mail: Kristin.Taylor@genzyme.com

Received June 23, 2014; Accepted September 24, 2014; Published October 02 2014

Citation: Taylor KM, Bajko J, Cabrera MS, Kremer C, Puttlitz BM, et al. (2014) S6 Kinase 2 Deficiency Improves Glucose Disposal in Mice Fed a High Fat Diet. J Diabetes Metab 5: 441 doi:10.4172/2155-6156.1000441

Copyright: @ 2014 Taylor KM, et al. This is an open-access article distributed under the terms of the Creative Commons Attribution License, which permits unrestricted use, distribution, and reproduction in any medium, provided the original author and source are credited. 
IACUC committee and the Guide for the Care and Use of Laboratory Animals (U.S. Department of Health and Human Services, NIH Publication no. 86-23).

Wild-type C57BL/6, A/J, and Balb/c mice were obtained from The Jackson Laboratory (Bar Harbor, ME). S6K2 knockout mice (S6K2/-) were obtained from George Thomas and the Friedrich Miescher Institute for Biomedical Research (Basel, Switzerland) [12]. Picolab rodent diet 20 (5053) was obtained from Lab Diet (St. Louis, MO) and fed ad libitum as standard diet (SD). Rodent diet with $60 \% \mathrm{kcal}$ from fat (D12492) was obtained from Research Diets (New Brunswich, NJ) and fed ad libitum as High Fat Diet (HFD).

\section{Serum chemistries}

Blood was collected via retro-orbital puncture into serum separator tubes. Cholesterol, glucose, $\mathrm{LDH}$ and triglycerides were analyzed with test kits from Randox using their Rx Daytona (Kearneysville, West Virginia) clinical chemistry analyzer. Serum ketone levels were analyzed using the Wako Total Ketone Body assay kit (415-73301, 41173401) according to the manufacturer's instructions (Richmond, VA).

\section{Glucose tolerance tests}

Glucose Tolerance Tests (GTTs) were performed on groups ( $\mathrm{n}=7)$ of C57BL/6 and S6K2-/- mice after 31-35 weeks on HFD or SD. Mice were fasted for $6 \mathrm{~h}$ before oral glucose gavage $(2 \mathrm{~g} / \mathrm{kg})$. Blood glucose levels were measured prior to gavage (time zero) and 30, 60 and 120 min following oral gavage [13].

\section{Insulin tolerance tests}

Insulin Tolerance Tests (ITTs) were performed on groups $(n=15)$ of C57BL/6 and S6K2-/- mice after 30-34 weeks on HFD or SD. Mice were fasted for $6 \mathrm{~h}$ followed by intraperitoneal insulin injections $(0.75 \mathrm{U} /$ $\mathrm{kg}$ ). Blood glucose levels were measured prior to insulin injection (time zero) and 30, 60 and 120 min following insulin injection.

\section{Preparation of tissue homogenates}

Tissue collection and protein determination by BCA were performed as previously described [14].

\section{Pancreatic collection and morphometric analysis of beta cells}

Pancreatic tissue was collected from age matched C57BL/6, S6K2-/, BALB/c, and $\mathrm{A} / \mathrm{J}$ mice. The tissues were fixed for 4 days in $10 \%$ neutral buffered formalin and embedded in paraffin, using standard protocols. The paraffin blocks were cut into 5 to 10 sets of 10 serial sections (4 $\mu \mathrm{m}$ thickness). Each set was separated by $200 \mu \mathrm{m}$. One tissue section from each set was deparaffinized by heat. Insulin antigen retrieval was performed by heating the samples at $95^{\circ} \mathrm{C}$ for $28 \mathrm{~min}$ in CC1 buffer from Ventana (Sunnyvale, CA) followed by incubation for $60 \mathrm{~min}$ at $37^{\circ} \mathrm{C}$ with a primary anti-insulin antibody from DAKO (Carpinteria, CA). Secondary antibody incubation was performed with biotinylated goat anti-guinea pig antibody from Rockland (Gilbertsville, PA) for 16 min at $37^{\circ} \mathrm{C}$. Sections were then incubated with the DAB Map streptavidinbiotin peroxidase detection system from Ventana (Sunnyvale, CA), counterstained with hematoxylin, and mounted with mounting media from Sakura (Torrance, CA). High-resolution whole slide images were captured with the Aperio ScanScope XT (Vista, CA) and the Aperio deconvolution algorithm was used to determine the total stained insulin positive area and the total tissue area. The total insulin positive area was used as a surrogate for $\beta$-cell mass. Hence, $\beta$-cell mass was calculated as the percentage of insulin positive stained area relative to the total assessed pancreas area expressed as means \pm SEM for each group (C57BL/6 HFD $n=8, C 57 B L / 6$ SD $n=10, S 6 K 2-/-$ HFD $n=6$, S6K2-/- SD n=7, BALB/c HFD n=7, A/J HFD n=7) in one experiment.

\section{Statistical analysis}

All of the data are expressed as the mean \pm SEM of two independent experiments. Data were analyzed by one-way ANOVA with NewmanKeuls comparing indicated treatment groups; ${ }^{\star}, \mathrm{P}<0.05{ }^{\star \star} \mathrm{P}<0.01{ }^{\star * *}$,
A

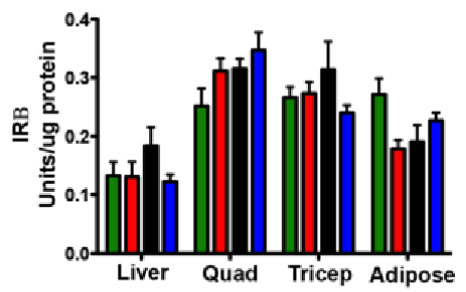

C

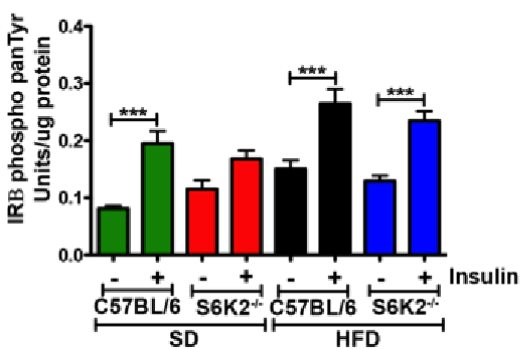

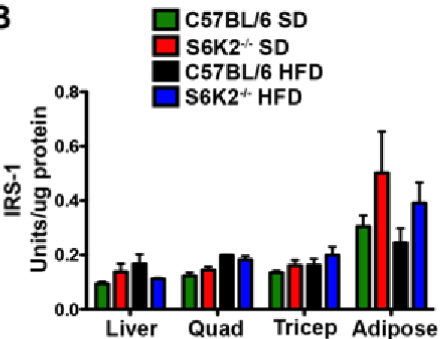

D

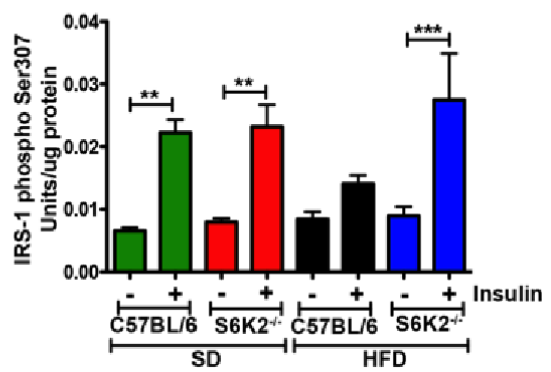

Figure 1: Insulin mediated phosphorylation of IRS-1 Ser307 in the triceps of C57BL/6 and S6K2-- mice.

A, IRß protein levels in designated tissue lysates. Starting at $7-10$ weeks of age, groups $(n=8)$ of C57BL/6 and S6K2-- male mice were fed SD or HFD for 31 weeks. $\mathrm{B}$, IRS-1 protein levels determined by ELISA. C, IR $\beta$ phosphorylation of panTyr in response to insulin. Tissues were collected 10 min after tail vein injection of insulin $(0.75 \mathrm{U} / \mathrm{kg})$. D, phosphorylation of IRS-1 Ser307 determined by ELISA ${ }^{* *} \mathrm{P}<0.01,{ }^{* * *} \mathrm{P}<0.001$. 
Citation: Taylor KM, Bajko J, Cabrera MS, Kremer C, Puttlitz BM, et al. (2014) S6 Kinase 2 Deficiency Improves Glucose Disposal in Mice Fed a High Fat Diet. J Diabetes Metab 5: 441 doi:10.4172/2155-6156.1000441

Page 3 of 7

$\mathrm{P}<0.001$ A probability value of $\mathrm{P}<0.05$ was considered to be statistically different.

\section{Results}

Expression and Phosphorylation of the insulin receptor beta Subunit (IR $\beta$ ) and Insulin Receptor Substrate 1 (IRS-1) in S6K2-/- mice on a SD or HFD

The mTOR pathway is known to regulate the level of IRS-1. For example, over activation of the pathway can cause depletion of IRS-1 protein levels [15]. Conversely, inactivation of mTOR in muscle robustly increases IRS-1 levels [16]. As S6K2 is downstream of the mTORC1 signaling pathway, we asked whether a reduction in its levels would affect the basal levels of IR $\beta$ and IRS- 1 . The levels of IR $\beta$ and IRS- 1 in liver, triceps, quadriceps, and adipose tissue in wild-type C57BL/6 and S6K2-/- $(n=8)$ mice regardless of whether they were fed a SD or HFD for 31 weeks were found to be similar (Figure 1A and B). This result suggests that $\mathrm{S} 6 \mathrm{~K} 2$ is not involved in the previously reported mTORC1 regulation of IRS-1 protein levels.

Stimulation of the insulin signaling pathway leads to the phosphorylation of IR $\beta$ and IRS-1 [17]. To evaluate the roles of diet and S6K2 on the phosphorylation of these two components of the pathway, we assayed the phosphorylation status of IR $\beta$ (panTyr) and IRS-1 (phosSer307) in triceps after intravenous insulin administration. In both wild-type and S6K2-/- mice $(\mathrm{n}=8)$ fed either a SD or HFD, activation of the pathway with insulin caused an increase in IR $\beta$ phosphorylation, $\mathrm{P}<0.001$ (Figure 1C). On a SD, provision of insulin induced a similar extent of IRS-1 phosphorylation in both wild-type and S6K2-/- mice, $\mathrm{P}<0.01$ (Figure 1D). However, wild-type C57BL/ 6 mice that had been placed on a HFD exhibited reduced insulin-mediated phosphorylation of IRS-1, suggesting an impairment of the pathway. Interestingly, this component of the pathway in S6K2-/- mice on the same HFD remained sensitive to insulin-mediated phosphorylation, $\mathrm{P}<0.001$ (Figure 1D).

\section{S6K2-/- Mice on a HFD exhibit improved glucose disposal and insulin sensitivity}

Starting at 10 weeks of age, S6K2-/- and wild-type C57BL/6 mice $(n=7)$ were placed on either a SD or HFD for 31 weeks. At the end of the study period, GTTs of wild-type mice that had been fed a HFD demonstrated qualitatively (Figure 2A) and quantitatively, $\mathrm{P}<0.001$ (Figure 2B) a reduced ability to dispose glucose when compared to their age-matched counterparts on a SD. These assays also demonstrated that glucose disposal in S6K2-/- mice on a SD was similar to that of wildtype mice and that this ability was unaffected by a HFD (Figures $2 \mathrm{~A}$ and B). Hence, S62K-/- mice would appear to be protected from developing diabetes.

On a SD, the basal insulin levels of S6K2-/- mice were determined to be higher than those of age-matched wild-type C57BL/6 mice, $\mathrm{P}<0.01$ (Figure $2 \mathrm{C}$ and $\mathrm{D}$ ). After 31 weeks on a HFD, the basal insulin levels of S6K2-/- mice remained similarly elevated. However, when placed on a HFD the basal insulin levels in wild-type mice increased to those observed in the S6K2-/- mice (Figure 2C and D). As the insulin levels of both S6K2-/- and wild- type mice were similar on a HFD, it could be surmised that the improved glucose disposal noted in S6K2-/ mice compared to wild-type mice on a HFD (Figure $2 \mathrm{~A}$ and B) was not due to differences in insulin levels. Rather, the results imply that insulin signaling remained more sensitive to insulin in the S6K2-/- mice than in wild- type mice.

To assess the insulin sensitivity of S6K2-/- and wild-type C57BL/6 mice $(\mathrm{n}=15)$ further, insulin was administered following a $6 \mathrm{~h}$ fast to mice that had been fed either a SD or HFD for 31 weeks. It should be noted that
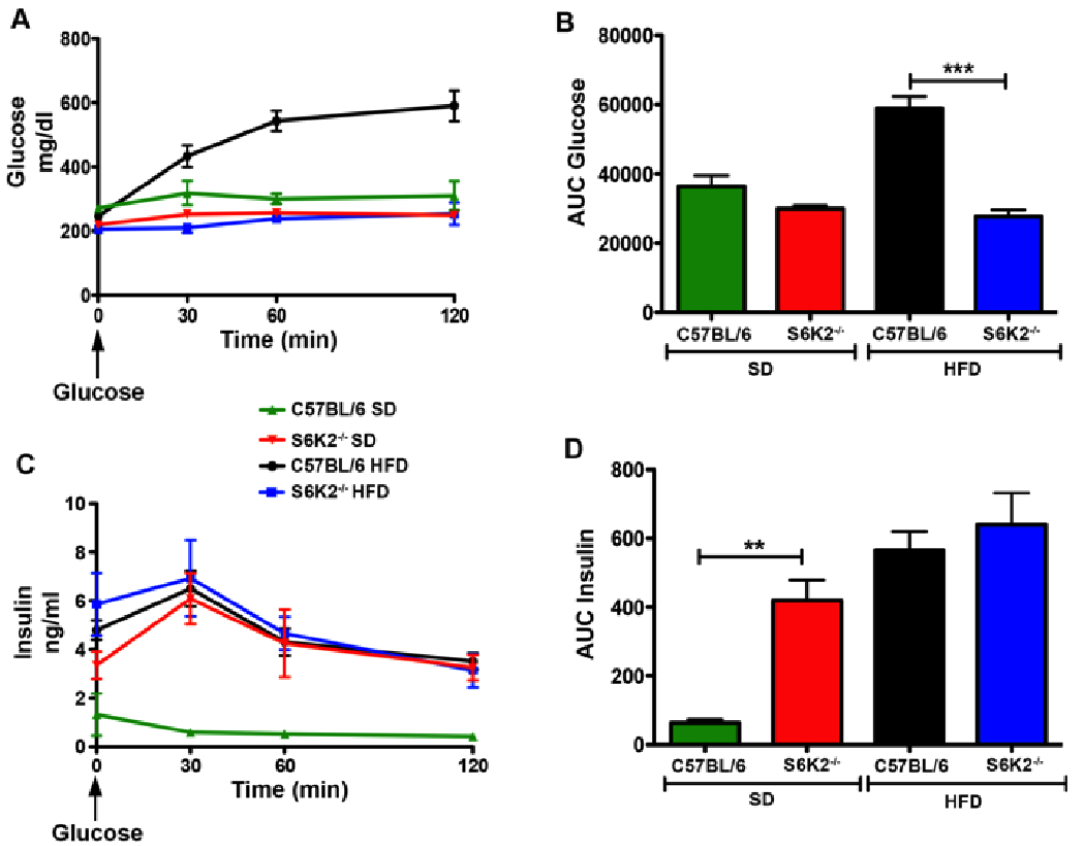

Figure 2: Glucose tolerance test in C57BL/6 and S6K2-1- mice.

A, GTTs were performed on the mice described in the legend to Fig. 1. Groups $(n=7)$ of C57BL/6 and S6K2/- mice were fasted for $6 \mathrm{~h}$ and then administered glucose by oral gavage $(2 \mathrm{~g} / \mathrm{kg})$. Blood glucose levels were measured prior to oral gavage (time zero) and 30,60 and 120 min following treatment. $B$, area under the curve (AUC) measurements performed on groups shown in A. C and D, blood insulin levels were measured prior to oral gavage of glucose (time zero) and 30,60 and 120 mins following treatment. ${ }^{* *} \mathrm{P}<0.01,{ }^{* * *} \mathrm{P}<0.001$ 
Citation: Taylor KM, Bajko J, Cabrera MS, Kremer C, Puttlitz BM, et al. (2014) S6 Kinase 2 Deficiency Improves Glucose Disposal in Mice Fed a High Fat Diet. J Diabetes Metab 5: 441 doi:10.4172/2155-6156.1000441

Page 4 of 7

prior to insulin administration, S6K2-/- mice (on either diet) had lower blood glucose levels than wild-type mice (Figure $3 \mathrm{~A}$ and $\mathrm{B}$ ). This was likely due to the elevated basal insulin levels in S6K2-/- mice as described in Fig. $2 \mathrm{C}$ and D. As expected, wild-type mice on a HFD were found to be less responsive to insulin than the corresponding cohort fed a SD, and exhibited an impaired ability to dispose of circulating glucose, $\mathrm{P}<0.001$ (Figure 3A and B). Interestingly, S6K2-/- mice placed on either a SD or

a HFD remained sensitive to insulin, and exhibited an ability to dispose of glucose similar to that of wild-type mice on a SD (Figure 3A and B).

Comparison of insulin responsiveness in S6K2-/- mice and diabetes resistant mouse strains

It has been reported that unlike $\mathrm{C} 57 \mathrm{BL} / 6$ mice, $\mathrm{BALB} / \mathrm{c}$ and $\mathrm{A} / \mathrm{J}$
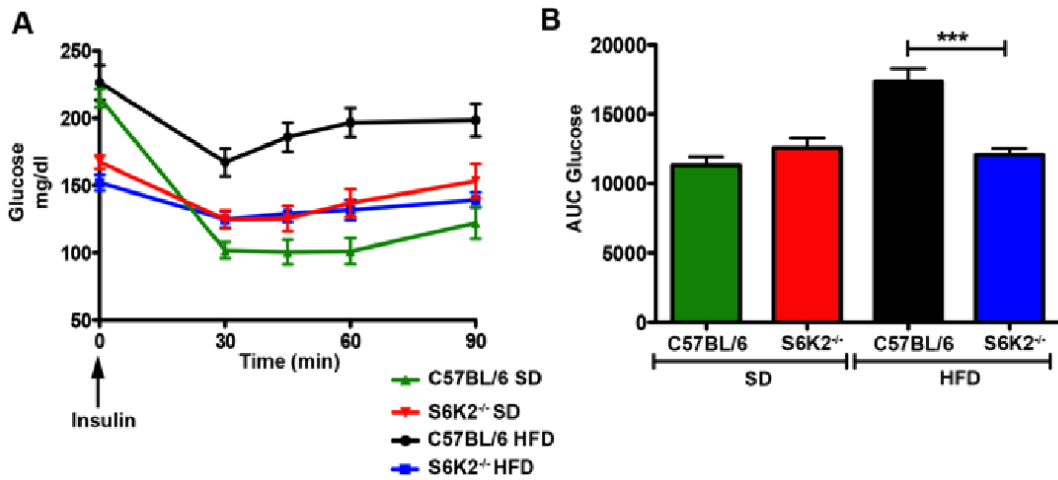

Figure 3: Insulin tolerance test in $\mathrm{C} 57 \mathrm{BL} / 6$ and $\mathrm{S} 6 \mathrm{~K}^{---}$mice

A, ITTs were performed on the mice described in the legend to Fig. 1. Groups $(n=15)$ of mice indicated were fasted for $6 \mathrm{~h}$ before being injected intraperitoneally with insulin $(0.75 \mathrm{U} / \mathrm{kg}$ ). Blood glucose levels were measured prior to insulin injection (time zero) and 30, 60 and 120 min following insulin administration. B, Area under the Curve (AUC) measurements performed on groups shown in $\mathrm{A} .{ }^{* * *} \mathrm{P}<0.001$.

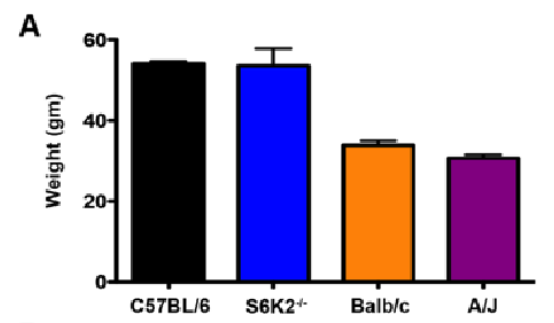

B

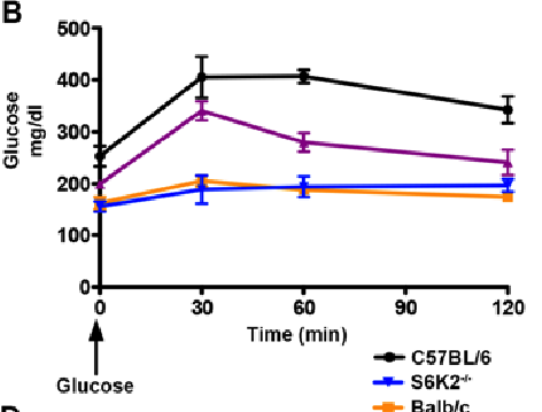

D

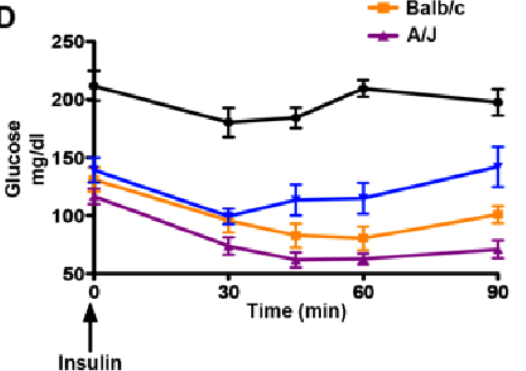

C
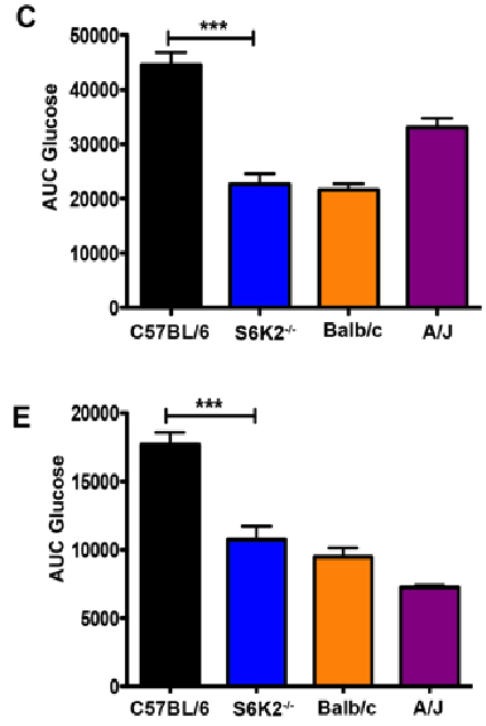

Figure 4: Glucose disposal in C57BL/6 and S6K2 $2^{-/-}$mice compared to diabetes resistant mice, BALB/C and A/J.

A, bodyweights of indicated strains after 35 weeks on HFD B, GTTs were performed as described in Figure 2 legend on groups ( $n=8$ ) of indicated strains after 34 weeks on HFD. C, area under the curve (AUC) measurements performed on groups shown in B. D, ITTs were performed as described in Figure 3 legend after 35 weeks on HFD. E, Area under the Curve (AUC) measurements performed on groups shown in $D$. ${ }^{* * *} \mathrm{P}<0.001$. 
Citation: Taylor KM, Bajko J, Cabrera MS, Kremer C, Puttlitz BM, et al. (2014) S6 Kinase 2 Deficiency Improves Glucose Disposal in Mice Fed a High Fat Diet. J Diabetes Metab 5: 441 doi:10.4172/2155-6156.1000441

Page 5 of 7

mice are resistant to developing diabetes when fed a HFD. The insulin responsiveness of S6K2-/- mice was compared to that of these diabetes resistant strains. Groups $(n=8)$ from all strains were fed a HFD for 35 weeks starting at 10 weeks of age. The C57BL/6 and S6K2-/- mice became obese while the $\mathrm{BALB} / \mathrm{c}$ and $\mathrm{A} / \mathrm{J}$ mice remained non-obese (Figure 4A). As expected, GTTs and ITTs of animals at the end of the study period demonstrated that C57BL/6 mice became glucose intolerant and insulin insensitive (Figure 4B-E). Surprisingly, although obese, the $\mathrm{S} 6 \mathrm{~K} 2-/$ - mice exhibited better glucose disposal characteristics than $\mathrm{C} 57 \mathrm{BL} / 6(\mathrm{P}<0.001)$ and $\mathrm{A} / \mathrm{J}$ mice and were similar to that of $\mathrm{BALB} / \mathrm{c}$ mice (Figure $4 \mathrm{~B}-\mathrm{E}$ ). Hence, in terms of insulin responsiveness, the S6K2-/- mice on a HFD would appear to be similar to the diabetes resistant strains $\mathrm{A} / \mathrm{J}$ and $\mathrm{BALB} / \mathrm{c}$.

Serum from S6K2-/- mice on a HFD was also collected under fed and fasted conditions and the resulting serum chemistry profiles compared to those of $\mathrm{BALB} / \mathrm{c}, \mathrm{A} / \mathrm{J}$, and C57BL/6 mice (Tables 1-4). It has been reported previously that the total ketones in S6K2-/- mice were $\sim 2$ fold higher in the fed state and $\sim 1.4$ fold higher in the fasted state than in wild-type mice [18]. As shown in Table 1, ketone levels in 8 week-old S6K2-/- mice (in the fed state) were slightly higher than those in C57BL/6 mice but lower than those in A/J mice. As expected, when the mice were fasted, the total ketone levels increased dramatically, but no difference was observed between S6K2-/- and C57BL/6 mice (Table

\begin{tabular}{|l|c|c|c|c|}
\hline Parameter & C57BL/6J & BALB/C & A/J & S6K2 $^{- \text {- }}$ \\
\hline Total Ketones, $\mu \mathrm{mol} / \mathrm{l}$ & $254.5 \pm 20.3$ & $222.1 \pm 16.5$ & $347.1 \pm 15.2$ & $280.2 \pm 39.3$ \\
\hline Leptin, $\mathrm{ng} / \mathrm{ml}$ & $1.85 \pm 0.23$ & $1.87 \pm 0.26$ & $3.61 \pm 0.46$ & $3.36 \pm 0.83$ \\
\hline Glucose, $\mathrm{mg} / \mathrm{dl}$ & $279.3 \pm 10.3$ & $238.8 \pm 10.4$ & $223.7 \pm 10.1$ & $244.4 \pm 16.8$ \\
\hline Cholesterol, $\mathrm{mg} / \mathrm{dl}$ & $77.4 \pm 2.8$ & $83.5 \pm 1.4$ & $68.8 \pm 1.9$ & $106.0 \pm 10.2^{*+*}$ \\
\hline $\mathrm{LDH}, \mathrm{U} / \mathrm{L}$ & $171.0 \pm 13.1$ & $169.6 \pm 12.2$ & $341.0 \pm 23.4$ & $146.4 \pm 6.9$ \\
\hline Triglycerides, $\mathrm{mg} / \mathrm{dl}$ & $130.7 \pm 17.2$ & $114.9 \pm 8.6$ & $125.5 \pm 7.6$ & $112.6 \pm 19.6$ \\
\hline
\end{tabular}

Each value represents means \pm S.E.M from groups of 8 mice.

${ }^{* * *} P<0.001$ between $\mathrm{C} 57 \mathrm{BL} / 6$ and S6K2-1- mice

Table 1: Serum chemistries of C57BL/6, BALB/c, A/J, and S6K2-- mice at 8 weeks of age fed SD. Mice were fed ad libitum prior to serum collection.

\begin{tabular}{|l|c|c|c|c|}
\hline Parameter & C57BL/6J & BALB/c & A/J & S6K2 $^{-/}$ \\
\hline Total Ketones, $\mu \mathrm{mol} / \mathrm{l}$ & $1684 \pm 167$ & $1251 \pm 206$ & $1555 \pm 262$ & $1572 \pm 284$ \\
\hline Insulin, $\mathrm{ng} / \mathrm{ml}$ & $0.21 \pm 0.02$ & $\mathrm{BDL}$ & $0.16 \pm 0.01$ & $0.49 \pm 0.14$ \\
\hline Adiponectin, $\mu \mathrm{g} / \mathrm{ml}$ & $9.46 \pm 0.54$ & $6.54 \pm 0.45$ & $7.12 \pm 0.57$ & $10.7 \pm 0.67$ \\
\hline Glucose, $\mathrm{mg} / \mathrm{dl}$ & $178.4 \pm 14.4$ & $162.1 \pm 13.1$ & $187.1 \pm 10.5$ & $168.0 \pm 36.9$ \\
\hline Cholesterol, $\mathrm{mg} / \mathrm{dl}$ & $83.7 \pm 1.5$ & $87.5 \pm 4.3$ & $66.4 \pm 2.5$ & $117.0 \pm 8.6$ \\
\hline $\mathrm{LDH}, \mathrm{U} / \mathrm{L}$ & $162.8 \pm 25.9$ & $235.4 \pm 52.6$ & $254.0 \pm 24.6$ & $128.4 \pm 15.8$ \\
\hline Triglycerides, $\mathrm{mg} / \mathrm{dl}$ & $68.4 \pm 2.0$ & $49.3 \pm 3.9$ & $62.8 \pm 2.8$ & $78.8 \pm 11.3$ \\
\hline
\end{tabular}

$\mathrm{BDL}$, below detection limit

Each value represents means \pm S.E.M from groups of 8 mice.

*** $P<0.001$ between C57BL/6 and S6K2 ${ }^{-/}$mice

Table 2: Serum chemistries of C57BL/6, BALB/c, A/J, and S6K2-- mice at 9 weeks of age fed SD. Mice were fasted for $16 \mathrm{~h}$ prior to serum collection.

\begin{tabular}{|l|c|c|c|c|}
\hline Parameter & C57BL/6J & BALB/c & A/J & S6K2 $^{-/-}$ \\
\hline Leptin, $\mathrm{ng} / \mathrm{ml}$ & $67.3 \pm 6.2$ & $7.8 \pm 1.2$ & $15.5 \pm 2.1$ & $35.7 \pm 6.2$ \\
\hline Glucose, $\mathrm{mg} / \mathrm{dl}$ & $252.9 \pm 14.1$ & $231.9 \pm 12.0$ & $200.0 \pm 7.1$ & $169.0 \pm 15.5$ \\
\hline Cholesterol, $\mathrm{mg} / \mathrm{dl}$ & $257.9 \pm 8.6$ & $144.4 \pm 5.1$ & $140.7 \pm 4.0$ & $223.0 \pm 23.7$ \\
\hline $\mathrm{LDH}, \mathrm{U} / \mathrm{L}$ & $937.9 \pm 114.7$ & $391.4 \pm 36.8$ & $455.7 \pm 42.3$ & $816.0 \pm 103.1$ \\
\hline Triglycerides, $\mathrm{mg} / \mathrm{dl}$ & $113.6 \pm 13.4$ & $126.3 \pm 13.5$ & $141.4 \pm 18.9$ & $143.0 \pm 21.9$ \\
\hline
\end{tabular}

Each value represents means \pm S.E.M from groups of 8 mice.

${ }^{* * *} P<0.001$ between $\mathrm{C} 57 \mathrm{BL} / 6$ and S6K2 ${ }^{-/-}$mice

Table 3: Serum chemistries of C57BL/6, BALB/c, A/J, and S6K2-- mice at 50 weeks of age fed SD for 10 weeks followed by HFD for 40 weeks. Mice were fed ad libitum prior to collection of serum.

\begin{tabular}{|l|c|c|c|c|}
\hline Parameter & C57BL/6J & BALB/c & A/J & S6K2 $^{-/}$ \\
\hline Total Ketones, $\mu \mathrm{mol} / \mathrm{l}$ & $650.6 \pm 89.0$ & $738.2 \pm 56.7$ & $868.7 \pm 115.3$ & $743.2 \pm 85.7$ \\
\hline Insulin, $\mathrm{ng} / \mathrm{ml}$ & $3.0 \pm 0.89$ & $.048 \pm 0.021$ & $.123 \pm 0.03$ & $1.5 \pm 0.30$ \\
\hline Adiponectin, $\mu \mathrm{g} / \mathrm{ml}$ & $17.1 \pm 0.86$ & $14.7 \pm 0.59$ & $9.3 \pm 0.31$ & $15.1 \pm 1.21$ \\
\hline Glucose, $\mathrm{mg} / \mathrm{dl}$ & $300.0 \pm 12.8$ & $191.9 \pm 6.1$ & $200.7 \pm 9.9$ & $220.0 \pm 12.2$ \\
\hline Cholesterol, $\mathrm{mg} / \mathrm{dl}$ & $247.1 \pm 8.4$ & $105.0 \pm 3.9$ & $110.0 \pm 4.6$ & $229.2 \pm 26.8$ \\
\hline LDH, U/L & $938.6 \pm 101.0$ & $401.3 \pm 48.1$ & $367.1 \pm 23.0$ & $562.5 \pm 61.9$ \\
\hline Triglycerides, $\mathrm{mg} / \mathrm{dl}$ & $53.6 \pm 8.9$ & $85.6 \pm 7.7$ & $94.3 \pm 8.3$ & $70.0 \pm 8.2$ \\
\hline
\end{tabular}

Each value represents means \pm S.E.M from groups of 8 mice.

*** $P<0.001$ between C57BL/6 and S6K2 ${ }^{-/}$mice

Table 4: Serum chemistries of C57BL/6, BALB/c, A/J, and S6K2-- mice at 51 weeks of age fed SD for 10 weeks followed by HFD for 41 weeks. Mice were fasted for 16 $\mathrm{h}$ prior to collection of serum.

2). Eight week-old S6K2-/- mice fed SD ad libitum had cholesterol levels of $106.0 \pm 10.2 \mathrm{mg} / \mathrm{dl}$ (Table 1) and $117.0 \pm 8.6 \mathrm{mg} / \mathrm{dl}$ when fasted for $16 \mathrm{~h}$ (Table 2). These levels were higher than those of the other strains, but were still within what is considered the normal range, viz., 50-120 $\mathrm{mg} / \mathrm{dl}[19]$. When placed on a HFD the cholesterol levels in the obese strains (wild-type C57BL/6 and S6K2-/- mice) exceeded the normal range to a similar extent (Table 4)

It is noteworthy that unlike S6K1-/- mice that are hypoinsulinemic, S6K2-/- mice on a SD have higher insulin levels than wild-type C57BL/6 $(\mathrm{P}<0.001), \mathrm{BALB} / \mathrm{c}$ and $\mathrm{A} / \mathrm{J}$ mice (Table 2; fasted for $16 \mathrm{~h}$ and Figure $2 \mathrm{C}$ fasted for $6 \mathrm{~h}$ ) [8]. After being placed on a HFD for 40 weeks, insulin levels in wild-type C57BL/6 mice (that had been fasted for 16 h) were 2-fold higher than those of S6K2-/- mice, yet the S6K2-/- mice had lower blood glucose levels (Table 4). This result suggests that S6K2/- mice have greater insulin sensitivity.

It was previously reported that $\mathrm{S} 6 \mathrm{~K} 1-/-$ mice have reduced $\beta$-cell mass compared to wild-type mice [8], and S6K1-/- mice fed a HFD have 10 fold lower insulin levels compared to wild-type mice [6]; therefore, we assessed the $\beta$-cell mass, which is defined as the percentage of the pancreatic tissue that stained positive for insulin, in 5 to 10 sections of pancreas from C57BL/6, BALB/c, A/J, and S6K2-/- mice ( $\mathrm{n}=6-10)$ that were fed a HFD, starting at 10 weeks of age for 44 weeks or remained on SD for 54 weeks. Representative anti-insulin stained images for each strain are shown in Figure 5A-F. As shown in Figure 5G and H, S6K2-/- mice have a 2.5 fold higher $\beta$-cell mass compared to wild-type C57BL/ 6 independent of diet. The mean insulin positive stained area in the pancreas for each strain on HFD was as follows: 3.3\% for S6K2-/-, $1.2 \%$ for $\mathrm{C} 57 \mathrm{BL} / 6,0.9 \%$ for $\mathrm{A} / \mathrm{J}$, and $0.8 \%$ for $\mathrm{BALB} / \mathrm{c}$ and on $\mathrm{SD}$ was: $2.9 \%$ for $\mathrm{S} 6 \mathrm{~K} 2-/-$ and $0.95 \%$ for $\mathrm{C} 57 \mathrm{BL} / 6$. This is consistent with the higher insulin levels observed in S6K2-/- mice shown in Tables 3 and 4.

The observed increase in insulin positive $\beta$-cell area was unexpected because inhibition of the mTORC1 pathway with rapamycin or S6K1 deficiency results in a reduction in $\beta$-cell mass and $\beta$-cell size (see "Discussion"). The novel observation that S6K2 deficiency increases $\beta$-cell mass provides an additional argument for the inhibition of $S 6 \mathrm{~K} 2$ as an approach to treat type 2 diabetes.

\section{Discussion}

It is well established that insulin signaling is mediated through the mTOR pathway [1-3]. Numerous cell culture studies have shown that hyperactivation of mTORC1 induces insulin resistance, and inhibition of mTORC1 with rapamycin restores insulin signaling $[15,20]$. The roles of mTORC1 in whole animal metabolism have been more difficult to assess because a knockout of any component of mTORC1 is embryonic lethal [21-23]. 

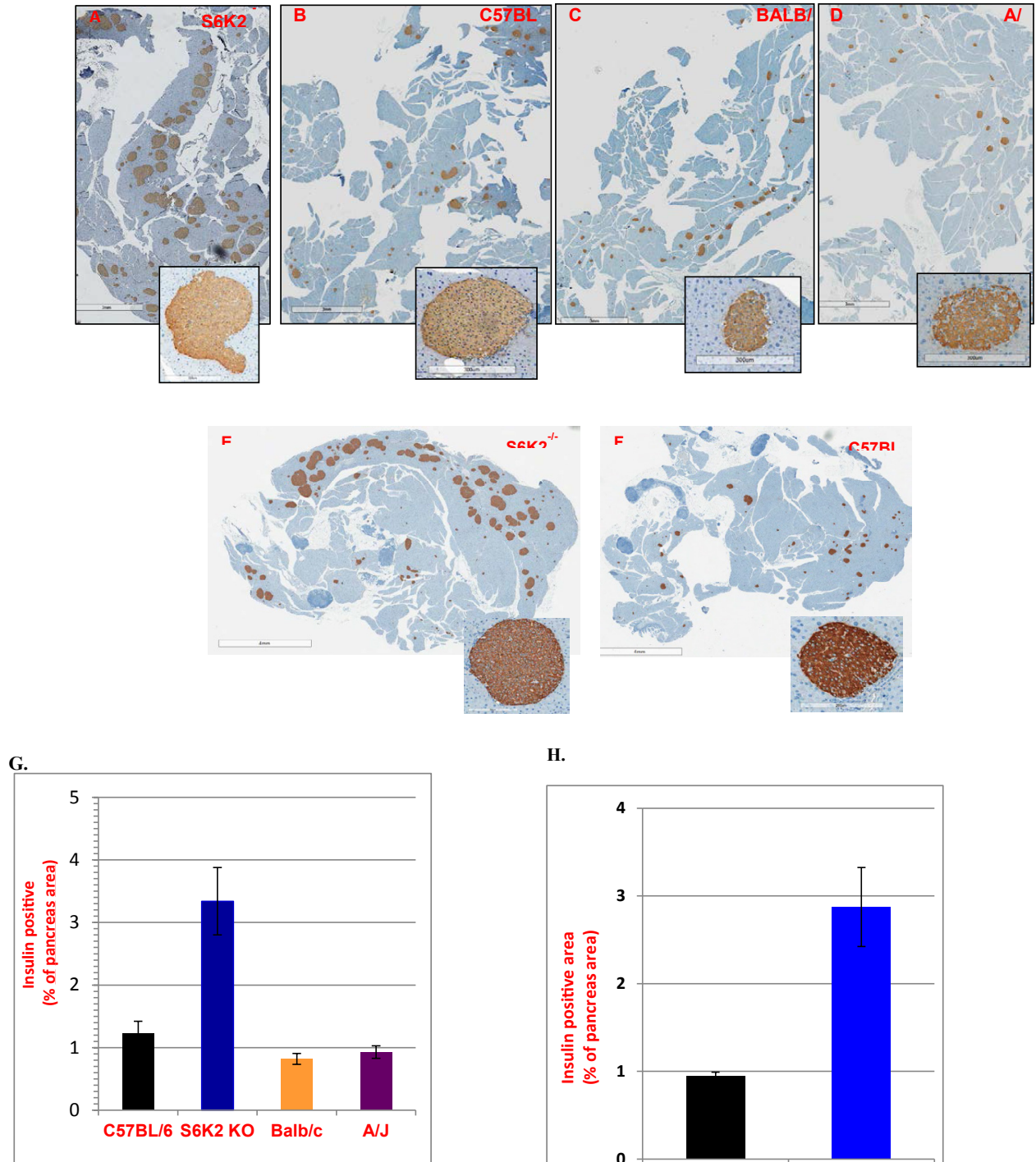

H.

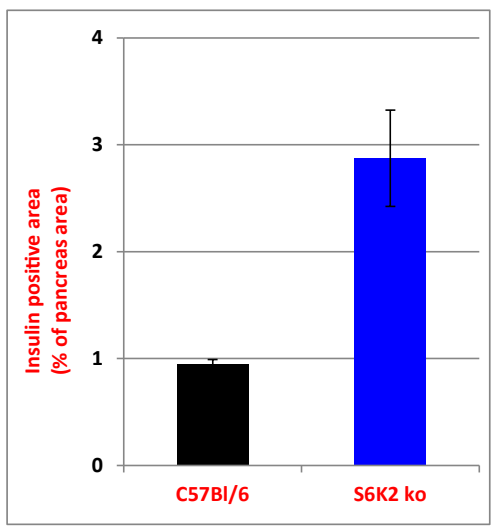

Figure 5: $\beta$-cell mass in S6K2 $2^{-/-}$mice

A-F are representative images used to calculate $\beta$-cell mass from anti-insulin stained pancreas sections (brown) counterstained with hematoxylin (blue). A-D, the indicated strains were fed a HFD (scale bars indicate $3 \mathrm{~mm}$ ) and inset images depict representative islets for each strain (scale bar $300 \mu \mathrm{m}$ ). E-F, the indicated strains were fed SD (scale bars indicate $4 \mathrm{~mm}$ ) and inset images depict representative islets for each strain (scale bar $200 \mu \mathrm{m}$ ). $\beta$-cell mass was calculated as the percentage of insulin positive stained area relative to the total assessed pancreas area. Five to ten nonconsecutive sections separated by $200 \mu \mathrm{m}$ were quantified for each pancreas ( $n=6-10$ mice for each group). G, $\beta$-cell mass quantitated from images A-D. H, $\beta$-cell mass quantitated from images $E$-F.

While tissue-specific inhibition of mTORC1 in adipose tissue improves glucose tolerance in mice, global inhibition of mTORC1 with rapamycin impairs glucose tolerance in rodents and humans [24-26]. The disparity in these results is likely because rapamycin is toxic to pancreatic $\beta$-cells, causing a reduction in $\beta$-cell mass and consequently lower glucose-stimulated insulin secretion $[25,26]$. This $\beta$-cell toxicity is possibly due to inhibition of the downstream mTORC1 effector S6K1, because S6K1-/- mice also have reduced $\beta$-cell mass, are hypoinsulinemic, and glucose intolerant [8].

Given the deleterious consequences associated with S6K1 deficiency, it was unexpected that a double knockout of S6K1 and S6K2 reversed the glucose intolerance observed in the S6K1 knockout alone [10]. This observation, combined with the finding that obese ob/ob mice have markedly elevated S6K2 activity, suggested to us that specifically inhibiting S6K2 alone might prove beneficial in type 2 diabetes and potentially avoid the deleterious effects associated with S6K1 inhibition [18].

This report demonstrates that S6K2 deficient mice have a 2.5 fold increase in $\beta$-cell mass compared to wild-type C57BL/ 6 mice, which is independent of diet. The increase in $\beta$-cell mass supports the higher insulin levels observed in the S6K2-/- mice fed SD. In contrast, on a HFD S6K2-/- mice have similar insulin levels compared to wild type mice but demonstrate improved glucose tolerance and insulin sensitivity. Hence, a deficiency of S6K2 would appear to confer some measure of resistance to developing diabetes.

Another novel observation noted from the studies here was that 
Citation: Taylor KM, Bajko J, Cabrera MS, Kremer C, Puttlitz BM, et al. (2014) S6 Kinase 2 Deficiency Improves Glucose Disposal in Mice Fed a High Fat Diet. J Diabetes Metab 5: 441 doi:10.4172/2155-6156.1000441

insulin-mediated phosphorylation of IRS-1 Ser307 was maintained in S6K2-/- mice but reduced in wild-type C57BL/6 mice on a HFD. The significance of Ser307 phosphorylation on IRS-1 in vivo has been tested directly in knock-in mice in which Ser307 was replaced with an alanine residue to prevent its phosphorylation [27]. These S307A mice were mildly diabetic on SD, but when fed a HFD they developed more severe insulin resistance and impaired muscle insulin signaling. Reduced phosphorylation of Ser307 has also been reported in tissues from diabetic patients compared to non-diabetic patients [17]. However, how S6K2 influences the phosphorylation state of Ser307 remains unclear. Several kinases have been reported to phosphorylate Ser307, including JNK1, IKK $\beta$, S6K1, mTOR, and PKCO [28]. Future studies to define the relationship of $S 6 \mathrm{~K} 2$ to these kinases should prove to be informative. It remains possible that the increased phosphorylation of IRS-1 Ser307 in S6K2-/- mice on a HFD is an associated phenomenon that does not contribute directly to the observed improvement in glucose disposal. Phosphomimetic mutation of IRS-1 serine 307 to aspartic acid (S307D) has also been studied in cell-based assays [29]. The results suggest that this site does not contribute substantially to insulin resistance. However, this single phosphomimetic mutation will have to be evaluated in knock-in mice fed SD and HFD before any final conclusions can be drawn.

\section{Conclusions}

In summary, the results of this study suggest that it is possible to manipulate the mTORC1 pathway to improve glucose tolerance without reducing insulin levels or $\beta$-cell mass. Indeed, inhibition of S6K2 specifically may represent a viable strategy for intervention in type 2 diabetes.

\section{Acknowledgments}

We thank Jennifer Johnson, Michelle Searles, Elizabeth Meyers, William Weber, and members of Genzyme's Department of Comparative Medicine for their technical assistance and valuable input.

\section{References}

1. Zoncu R, Efeyan A, Sabatini DM (2011) mTOR: from growth signal integration to cancer, diabetes and ageing. Nat Rev Mol Cell Biol 12: 21-35.

2. Howell JJ, Manning BD (2011) mTOR couples cellular nutrient sensing to organismal metabolic homeostasis. Trends Endocrinol Metab 22: 94-102.

3. Polak P, Hall MN (2009) mTOR and the control of whole body metabolism. Curr Opin Cell Biol 21: 209-218.

4. Düvel K, Yecies JL, Menon S, Raman P, Lipovsky Al, et al. (2010) Activation of a metabolic gene regulatory network downstream of mTOR complex 1 . Mol Cell 39: 171-183.

5. Ashe K M, Taylor K M, Chu Q, Meyers E, Ellis A, et al. (2010) Inhibition of glycogen biosynthesis via mTORC1 suppression as an adjunct therapy for Pompe disease. Mol Genet Metab 100: 309-315.

6. Um S H, Frigerio F, Watanabe M, Picard F, Joaquin M, et al.(2004) Absence of S6K1 protects against age- and diet-induced obesity while enhancing insulin sensitivity. Nature 431: 200-205

7. Younis H S, Hirakawa B, Scott W, Tran P, Bhat G, et al.(2011) Antisense inhibition of $\mathrm{S} 6$ kinase 1 produces improved glucose tolerance and is well tolerated for 4 weeks of treatment in rats. Pharmacology 87:11-23.

8. Pende M, Kozma SC, Jaquet M, Oorschot V, Burcelin R, et al. (2000) Hypoinsulinaemia, glucose intolerance and diminished beta-cell size in S6K1deficient mice. Nature 408: 994-997.

9. Magnuson B, Ekim B, Fingar DC (2012) Regulation and function of ribosomal protein $\mathrm{S} 6$ kinase (S6K) within mTOR signalling networks. Biochem J 441: 1-21.

10. Castañeda TR, Abplanalp W, Um SH, Pfluger PT, Schrott B, et al. (2012) Metabolic control by S6 kinases depends on dietary lipids. PLoS One 7 : e32631.
11. Clee SM, Attie AD (2007) The genetic landscape of type 2 diabetes in mice. Endocr Rev 28: 48-83.

12. Pende M, Um S H, Mieulet V, Sticker M, Goss V L, et al. (2004) S6K1(-/-) S6K2(-/-) mice exhibit perinatal lethality and rapamycin-sensitive 5'-terminal oligopyrimidine mRNA translation and reveal a mitogen-activated protein kinase-dependent S6 kinase pathway. Mol Cell Biol 24: 3112-3124.

13. Andrikopoulos S, Blair AR, Deluca N, Fam BC, Proietto J (2008) Evaluating the glucose tolerance test in mice. Am J Physiol Endocrinol Metab 295: E1323 1332.

14. Taylor KM, Meyers E, Phipps M, Kishnani PS, Cheng SH, et al. (2013) Dysregulation of multiple facets of glycogen metabolism in a murine model of Pompe disease. PLoS One 8: e56181.

15. Shah OJ, Wang Z, Hunter T (2004) Inappropriate activation of the TSC/Rheb/ mTOR/S6K cassette induces IRS1/2 depletion, insulin resistance, and cell survival deficiencies. Curr Biol 14: 1650-1656.

16. Risson V, Mazelin L, Roceri M, Sanchez H, Moncollin V, et al. (2009) Muscle inactivation of mTOR causes metabolic and dystrophin defects leading to severe myopathy. J Cell Biol 187: 859-874

17. Brännmark C, Nyman E, Fagerholm S, Bergenholm L, Ekstrand EM, et al. (2013) Insulin signaling in type 2 diabetes: experimental and modeling analyse reveal mechanisms of insulin resistance in human adipocytes. J Biol Chem 288: $9867-9880$.

18. Kim K, Pyo S, Um S H (2012) S6 kinase 2 deficiency enhances ketone body production and increases peroxisome proliferator-activated receptor alpha activity in the liver. Hepatology 55: 1727-1737

19. Jiao S, Cole TG, Kitchens RT, Pfleger B, Schonfeld G (1990) Genetic heterogeneity of lipoproteins in inbred strains of mice: analysis by gelpermeation chromatography. Metabolism 39: 155-160.

20. Tremblay F, Gagnon A, Veilleux A, Sorisky A, Marette A (2005) Activation of the mammalian target of rapamycin pathway acutely inhibits insulin signaling to Akt and glucose transport in 3T3-L1 and human adipocytes. Endocrinology 146: $1328-1337$

21. Gangloff YG, Mueller M, Dann SG, Svoboda P, Sticker M, et al. (2004) Disruption of the mouse mTOR gene leads to early postimplantation lethality and prohibits embryonic stem cell development. Mol Cell Biol 24: 9508-9516.

22. Murakami M, Ichisaka T, Maeda M, Oshiro N, Hara K, et al. (2004) mTOR is essential for growth and proliferation in early mouse embryos and embryonic stem cells. Mol Cell Biol 24: 6710-6718.

23. Guertin DA, Stevens DM, Thoreen CC, Burds AA, Kalaany NY, et al. (2006) Ablation in mice of the mTORC components raptor, rictor, or mLST8 reveals that $\mathrm{mTORC2}$ is required for signaling to Akt-FOXO and PKCalpha, but not S6K1. Dev Cell 11: 859-871.

24. Polak P, Cybulski N, Feige JN, Auwerx J, Rüegg MA, et al. (2008) Adiposespecific knockout of raptor results in lean mice with enhanced mitochondrial respiration. Cell Metab 8: 399-410.

25. Barlow AD, Nicholson ML, Herbert TP (2013) Evidence for rapamycin toxicity in pancreatic $\hat{l}^{2}$-cells and a review of the underlying molecular mechanisms. Diabetes 62: 2674-2682.

26. Fraenkel M, Ketzinel-Gilad M, Ariav Y, Pappo O, Karaca M, et al. (2008) mTOR inhibition by rapamycin prevents beta-cell adaptation to hyperglycemia and exacerbates the metabolic state in type 2 diabetes. Diabetes 57: 945-957.

27. Copps KD, Hancer NJ, Opare-Ado L, Qiu W, Walsh C, et al. (2010) Irs1 serine 307 promotes insulin sensitivity in mice. Cell Metab 11: 84-92.

28. Boura-Halfon S1, Zick Y (2009) Phosphorylation of IRS proteins, insulin action and insulin resistance. Am J Physiol Endocrinol Metab 296: E581-591.

29. Weigert C, Kron M, Kalbacher H, Pohl A K, Runge H, et al. (2008) Interplay and effects of temporal changes in the phosphorylation state of serine-302, -307 , and -318 of insulin receptor substrate-1 on insulin action in skeletal muscle cells. Mol Endocrinol 22: 2729-2740. 